\title{
EFFECT OF AMMONIUM NITRATE AND POTASSIUM HUMATE ON VEGETATIVE GROWTH AND CHEMICAL CONSTITUENTS OF CALOTROPIS PROCERA PLANTS.
}

Selim, S. M.*; Hend, E. Wahba ${ }^{* *}$; Hassanen, M. A***. and Wafaa, M. Abd El- Salam

* Prof. of Floriculture, Medicinal \& Aromatic plants, Hort. Dept., Fac. Agric., Fayoum Univ.

** Prof. of Medicinal\& Aromatic plants, National Research Center.

*** Assistant Prof. of Floriculture, Medicinal \& Aromatic plants, Hort. Dept., Fac.

Agric., Fayoum Univ.

\begin{abstract}
:
The present work aimed to study the influence of three gradual rates of nitrogenous fertilizer (ammonium nitrate; $\mathrm{NH}_{4} \mathrm{NO}_{3}$ ) and potassium humate at four doses and their interactions on vegetative growth and chemical constituents of Calotropis procera plants. The obtained results showed that all morphological characteristics i.e. plant height, stem diameter, number of branches and leaves per plant, leaf area per plant, plant fresh and dry weights, root fresh and dry weights were inceased by application of different rates of $\mathrm{NH}_{4} \mathrm{NO}_{3}$ and potassium humate fertilizer or their combinations. Also, plants treated with $\mathrm{NH}_{4} \mathrm{NO}_{3}$ and potassium humate fertilizers showed a significant increase in the contents of chlorophyll $\mathrm{A}$ and $\mathrm{B}$, carotenoids, total carbohydrates(\%), N\%- $\mathrm{P} \%-\mathrm{K} \%$ and total alkaloids of Calotropis procera leaves as compared untreated (control) plant. While total phenolic and total flavonoids contents were decreased with fertilization by different rates of $\mathrm{NH}_{4} \mathrm{NO}_{3}$ and potassium humate. The highest values of total phenolic and total flavonoids contents were obtained with applied the lowest fertilizer rates of $\mathrm{NH}_{4} \mathrm{NO}_{3}(1 \mathrm{~g} /$ plant $)$ and potassium humate at zero level.
\end{abstract}

\section{INTRODUCTION}

Calotropis procera is a flowering shrub of the family Asclepediaceae. It is famous with different names based on its habitat, such as Dead Sea plant, Kisher and Usher in Arabic; Dead Sea fruit, Desert wick, Giant milkweed, Mudar fibre, Rubber tree, Rubber bush, Swallow-wort and Sodom apple in English; Akdo, Akada and Madar in Indian (Farooq et al., 2014 ; Kumar et al., 2013).

Calotropis procera is one of the important numbers of traditional herbal medicine in many countries. It has been reported to possess numerous medicinal properties. In the traditional Asian medical system, it has been used for bronchitis, pain, asthma and tumors. The plant is also known for its toxic

Fayoum J. Agric. Res. \& Dev., Vol. 32, No.2, July, 2018 
Selim, S. M.*; et al.,

properties that include dermatitis, iridocyclites, and acts like a poison and produces lethal effects (Muzammal, 2014). The root skin, latex, flowers, leaves and the ksara of arka are used for medicinal purposes. Milk weed is useful both, internally and externally (Khairnar et al., 2012). The latex of Calotropis procera extract is easily available and is used in medicine for treatment of many diseases (Kumar $\boldsymbol{e t} \boldsymbol{a l}$., 2013). It is also used against malaria and skin infection. The milky latex and flowers were considered to improve digestion, Catarrh, and increases appetite (Muzammal, 2014 and Seifu, 2004). Leaves and roots of this plant have been used to relieve pain under different onditions (Dewan $\boldsymbol{e t}$ al., 2000).

\section{Material and methods:}

This study was designed to assess the main effects of three nitrogen fertilizer rates (1,2 and $4 \mathrm{~g}$ of ammonium nitrate / plant) and application of potassium humate as a soil drench at four concentrations $(0,4,8$ and $12 \mathrm{~g} /$ plant $)$ on vegetative growth and chemical composition of Calotropis procera wild plant . Tow pot experiments were conducted at a privet farm at Tezment village - Bani Sweif Governorate during the two successive seasons of 2015 and 2016. Seeds of Calotropis procera plant were collected from wild plants grown in Beni Suef desert. Black plastic bags $30 \times 40 \mathrm{~cm}$ were prepared and field with 15 $\mathrm{kg}$ sandy clay loam soil. Before sowing the seed in the two seasons, soil samples were analyzed at Soil Testing Laboratory, Faculty of Agriculture, Fayoum University according to the standard published procedures (Wilde $\boldsymbol{e t}$ al., 1985). Results of soil samples analysis are presented in Table 1.

Fayoum J. Agric. Res. \& Dev., Vol. 32, No.2, July, 2018 
EFFECT OF AMMONIUM NITRATE AND POTASSIUM HUMATE.... 105 Table (1): Some physical and chemical characteristics of the experimental site in two seasons.

\begin{tabular}{|c|c|c|}
\hline Properties & 2015 & 2016 \\
\hline \multicolumn{3}{|l|}{ Physical properties } \\
\hline Clay & 27.3 & 25.7 \\
\hline Silt & 20.2 & 23.2 \\
\hline Fine sand & 52.5 & 51.1 \\
\hline Soil texture & Sandy Clay Loam & SandyClay Loam \\
\hline \multicolumn{3}{|l|}{ Chemical properties } \\
\hline $\mathbf{P H}$ & 7.6 & 7.8 \\
\hline ECe $\left(\mathrm{dsm}^{-1}\right)$ & 3.52 & 3.74 \\
\hline Organic matter $(\%)$ & 2.56 & 2.86 \\
\hline $\mathrm{Ca} \mathrm{CO}_{3} \quad(\%)$ & 6.1 & 6.6 \\
\hline \multicolumn{3}{|l|}{ Cations (m. eq /L) } \\
\hline $\mathbf{C a}^{++}$ & 17.2 & 17.5 \\
\hline $\mathbf{M g}^{++}$ & 6.8 & 6.5 \\
\hline $\mathbf{N}^{+}$ & 13.2 & 13.6 \\
\hline $\mathbf{K}^{+}$ & 0.8 & 0.7 \\
\hline \multicolumn{3}{|l|}{ Anions (m.eq/L) } \\
\hline $\mathrm{Cl}^{-}$ & 20.5 & 21.3 \\
\hline $\mathrm{HCO}_{3}^{-}$ & 1.2 & 1.4 \\
\hline $\mathrm{SO}_{4}^{-}$ & 16.3 & 17.1 \\
\hline \multicolumn{3}{|l|}{ Major elements (mg/L) } \\
\hline $\mathbf{N}$ & 14 & 13 \\
\hline $\mathbf{P}$ & 22 & 20 \\
\hline $\mathbf{K}$ & 72 & 69 \\
\hline \multicolumn{3}{|l|}{ Trace elements (mg/L) } \\
\hline $\mathbf{F e}$ & 3.3 & 3.7 \\
\hline $\mathbf{Z n}$ & 0.4 & 0.3 \\
\hline Mn & 0.7 & 0.9 \\
\hline
\end{tabular}

Four seeds were sown in each black plastic bag on $9^{\text {th }}$ March, 2015 and 2016 seasons. After formation of 4 leaves, (about 45 days) seedlings were thinned to one seedling per bag. All plants were fertilized with $3 \mathrm{~g}$ of super phosphate $\left(15.5 \% \mathrm{P}_{2} \mathrm{O}_{5}\right)$ and $1 \mathrm{~g}$ of potassium sulphate $\left(48 \% \mathrm{~K}_{2} \mathrm{O}\right)$. On the first of June, the plants were treated with Ammonium nitrate $(33 \% \mathrm{~N})$ at the rates of $1 \mathrm{~g}$ (control), 2 and $4 \mathrm{~g}$ /plant. Potassium humate at rates of $(0,4,8$ and $12 \mathrm{~g} / \mathrm{plant})$ were applied as a soil drench for three times, monthly intervals and the first addition was done on $2^{\text {th }}$ June, in the two seasons of study.

The experimental layout was a split-plot in randomized complete blocks design with three replicates each replicate was represented five pags. Nitrogen fertilizer rates were applied as the main plots whilst, potassium humate levels

Fayoum J. Agric. Res. \& Dev., Vol. 32, No.2, July, 2018 
Selim, S. M.*; et al.,

were occupied the sub-plots and every treatment contained 5 plants. At the end of each growing season, ( $30^{\text {th }}$ September) the following data were collected. Morphological characters, i.e. plant height $(\mathrm{cm})$, number of branches plant $^{-1}$, stem diameter, number of leaves plant ${ }^{-1}$, leaf area plant ${ }^{-1}\left(\mathrm{~cm}^{2}\right)$, fresh weight of the above - ground vegetative growth (g), dry weight of the above - ground vegetative growth $(\mathrm{g})$, root fresh weight $(\mathrm{g})$, root dry weight $(\mathrm{g})$. Chemical analysis, i.e. chlorophyll $\mathrm{A}$ and $\mathrm{B}$ and carotenoids were calculated according to Moran (1982), leaf $\mathrm{N}$ content according to Hafez and Mikkelsen (1981), leaf $\mathrm{P}$ content according to A. O. A. C (1995), leaf K content according to Wilde et al. (1985), total carbohydrates content according to Herbert et al. (1971), total phenolics content according to (Ainsworth and Gillespie, 2007), total flavonoids content according to (Zhishen et al., 1999) and total alkaloids content according to (Woo et al., 1977). Appropriate analysis of variance was performed on results of each experiment. Comparisons among means of different treatments were performed using Least Significant Difference (L.S.D.) procedure at probability of 0.05 level as illustrated by Snedecor and Cochran (1980).

\section{Results and Discussion}

\section{Morphological Characters:}

\section{I.1. Plant height (cm):}

The data in Table (2) show that plant height increased as ammonium nitrate fertilizer rate increased and the most effective rate was $4 \mathrm{~g} /$ plant. This was true in the two seasons. This results were in accordance with Mohammadali et al. (2012) on tobacco plant (Nicotiana tabacum L.) and Ibrahim (2013) on Datura (Datura innoxia Mill.)

Table (2): Effect of nitrogen and potassium humate (KH) on plant height (cm) of Calotropis procera plant in two seasons.

\begin{tabular}{|c|c|c|c|c|c|c|c|c|}
\hline \multirow{2}{*}{ Humic/g $\quad \mathrm{NH}_{4} \mathrm{NO}_{3} / \mathrm{g}$} & \multicolumn{4}{|c|}{ first season (2015) } & \multicolumn{4}{|c|}{ second season (2016) } \\
\hline & 1 & 2 & 4 & Mean & 1 & 2 & 4 & Mean \\
\hline 0 & 42.7 & 46.9 & 50.7 & 46.8 & 39.7 & 42.6 & 47.4 & 43.2 \\
\hline 4 & 57.5 & 61.8 & 71.2 & 63.5 & 46.0 & 50.8 & 59.7 & 52.1 \\
\hline 8 & 65.0 & 74.9 & 77.8 & 72.6 & 57.9 & 64.4 & 71.0 & 64.4 \\
\hline 12 & 71.3 & 77.4 & 78.9 & 75.9 & 63.8 & 67.1 & 72.5 & 67.8 \\
\hline Mean & 59.1 & 65.2 & 69.6 & & 51.8 & 56.2 & 62.6 & \\
\hline $\begin{array}{c}\text { L.S.D } 5 \% \\
\mathbf{N} \\
\mathbf{K H} \\
\mathbf{N} \times \mathbf{K H}\end{array}$ & \multicolumn{4}{|c|}{2.4} & \multicolumn{4}{|c|}{4.6} \\
\hline
\end{tabular}

Fayoum J. Agric. Res. \& Dev., Vol. 32, No.2, July, 2018 
EFFECT OF AMMONIUM NITRATE AND POTASSIUM HUMATE.... 107

The highest values were 75.9 and $67.8 \mathrm{~cm}$ obtained from plants treated with potassium humate at the highest rate $(12 \mathrm{~g})$ per plant. This was true in the first and second seasons, respectively. Similar conclusions were reported by Mohammadipour et al. (2012) on (Calendula officinalis L.) plants, Aisha et al. (2014) on (Brassica rapa) plant and Said-Al Ahl et al. (2016) on dill plants.

The interaction between $\mathrm{NH}_{4} \mathrm{NO}_{3}$ and potassium humate was insignificant. The highest values were 75.9 and 72.5 obtained from plants treated with $\mathrm{NH}_{4} \mathrm{NO}_{3}$ at $4 \mathrm{~g}$ and potassium humate $12 \mathrm{~g}$ in the two seasons, respectively.

\section{Number of branches per plant:}

The tabulated data in Table (3) showed that when the rate of ammonium nitrate increased from $1 \mathrm{~g} /$ plant to $2 \mathrm{~g} /$ plant the number of branches per plant significantly increased but when the rate increased from 2 to $4 \mathrm{~g} /$ plant the number of branches increased, but the increment not enough to be significant compared to $2 \mathrm{~g}$ / plant, while was significant compared with the lowest level (1g/ plant). This trend was obtained during the two seasons of the study. Similar conclusions were reported by Rasmia et al., (2009) on (Catharanthus roseus G. Don), Azza et al. (2010) on caraway (Carum carvi L.) plants, Ahmadi (2010) on (Brassica napus L.), Rüveyde et al. (2011) on fenugreek plants and Ibrahim (2013) on (Datura innoxia Mill.) plants.

Table (3): Effect of nitrogen and potassium humate $(\mathrm{KH})$ on number of main branches /plant of Calotropis procera plant in two seasons.

\begin{tabular}{|c|c|c|c|c|c|c|c|c|}
\hline \multirow{2}{*}{$\begin{array}{lll}\text { Humic/g } & \mathrm{NH}_{4} \mathrm{NO}_{3} / \mathrm{g} \\
\end{array}$} & \multicolumn{4}{|c|}{ first season (2015) } & \multicolumn{4}{|c|}{ second season (2016) } \\
\hline & 1 & 2 & 4 & Mean & 1 & 2 & 4 & Mean \\
\hline $\mathbf{0}$ & 2.4 & 3.1 & 3.4 & 3.0 & 2.5 & 2.7 & 2.9 & 2.7 \\
\hline 4 & 3.4 & 4.0 & 4.7 & 4.0 & 3.1 & 3.6 & 4.0 & 3.6 \\
\hline 8 & 3.9 & 4.8 & 5.7 & 4.8 & 3.4 & 4.7 & 5.0 & 4.4 \\
\hline 12 & 4.9 & 5.5 & 5.6 & 5.3 & 3.8 & 5.0 & 5.1 & 4.6 \\
\hline Mean & 3.7 & 4.3 & 4.8 & & 3.2 & 4.0 & 4.3 & \\
\hline $\begin{array}{c}\text { L.S.D } 5 \% \\
\mathbf{N}\end{array}$ & \multicolumn{4}{|c|}{0.6} & \multicolumn{4}{|c|}{0.5} \\
\hline$\underset{\mathbf{N} \times \mathbf{K H}}{\mathbf{K} H}$ & \multicolumn{4}{|c|}{$\begin{array}{l}0.5 \\
0.5\end{array}$} & \multicolumn{4}{|c|}{$\begin{array}{l}0.3 \\
0.6\end{array}$} \\
\hline
\end{tabular}

Regarding the effect of potassium humate, there was a significant positive relationship in the first season between the levels of potassium humate and the number of branches per plant. As the levels of potassium humate increased the number of branches / plant increased significantly. In the second season, adding 4 or $8 \mathrm{~g} /$ plant of potassium humate caused a gradual significant increase in number of branches on the plant compared with the control, while adding $12 \mathrm{~g}$ /plant caused not significant increase in the number of branches compared with 8

Fayoum J. Agric. Res. \& Dev., Vol. 32, No.2, July, 2018 
Selim, S. M.*; et al.,

or $4 \mathrm{~g}$ in the same time in which was significant compared to the untreated plants. The same trend was concluded by Gomaa and Youssef (2008) on caraway plants, Bhatti et al.(2011) on mustard plant, and Mohammadipour et al. (2012) on (Calendula officinalis L.) plants.

The interaction between $\mathrm{NH}_{4} \mathrm{NO}_{3}$ and potassium humate was significant. The most effect treatment in this respect was $\mathrm{NH}_{4} \mathrm{NO}_{3}$ at the rate of $4 \mathrm{~g}$ and potassium humate at the rate of $8 \mathrm{~g}$ in the first season, while in the second seasons. The most effect treatment in this respect was $\mathrm{NH}_{4} \mathrm{NO}_{3}$ at the rate of $4 \mathrm{~g}$ / plant and potassium humate at the rate of $812 \mathrm{~g} /$ plant.

\section{Number of leaves per plant:}

The results in Table (4) showed that the highest number of leaves per plant were (48 and 47 leaves) recorded in the seasons of 2015 and 2016, respectively with the treatment of the highest rate of ammonium nitrate $(4 \mathrm{~g} /$ plant). Similar results were reported by Hossein et al. (2011) on (Nicotiana tabacum L.) plants, Mohammad Ali et al. (2012) on tobacco plants, Gholizadeh et al. (2012) on tobacco plants, Ibrahim (2013) on datura (Datura innoxia Mill.) plants and Shafeek et al. (2016) on (Cucurbita peop cv. Eskandarani) plants.

Concerning to the effect of potassium humate treatment, the results clearly showed that all treatments with potassium humate significantly increased the number of leaves per plant and the highest level of potassium humate $(12 \mathrm{~g} /$ plant) recorded the highest number of leaves on the plant (51.4 and 49.0 leaves /plant) compared with the untreated plants (control) in the 2015 and 2016 seasons, orderly. These results agreed with those obtained by Mohammadipour et al., (2012) on (Calendula officinalis L.) plants, Aisha et al. (2014) on (Brassica rapa) plant, Zeinali et al., (2015) on garlic (Allium sativum L.) plants, and Nadia et al. (2015) on okra (Hibiscus Esculantus) plants.

The interaction between $\mathrm{NH}_{4} \mathrm{NO}_{3}$ and potassium humate was significant. The highest values were 58.7 and 57.9 obtained from plants treated with $\mathrm{NH}_{4} \mathrm{NO}_{3}$ at $4 \mathrm{~g} /$ plant and potassium humate $12 \mathrm{~g} /$ plant in the two seasons, respectively.

Fayoum J. Agric. Res. \& Dev., Vol. 32, No.2, July, 2018 
EFFECT OF AMMONIUM NITRATE AND POTASSIUM HUMATE.... 109

Table (4): Effect of nitrogen and potassium humate (KH) on number of leaves /

plant of Calotropis procera plant during the two seasons.

\begin{tabular}{|c|c|c|c|c|c|c|c|c|}
\hline \multirow{2}{*}{ Humic/g Nitrogen $/ g$} & \multicolumn{4}{|c|}{ first season (2015) } & \multicolumn{4}{|c|}{ second season (2016) } \\
\hline & 1 & 2 & 4 & Mean & 1 & 2 & 4 & Mean \\
\hline 0 & 20.6 & 23.0 & 27.3 & 23.6 & 23.4 & 28.3 & 31.1 & 27.6 \\
\hline 4 & 28.1 & 38.4 & 47.8 & 38.1 & 26.8 & 34.2 & 43.0 & 34.7 \\
\hline 8 & 35.7 & 51.0 & 58.2 & 48.3 & 28.9 & 50.3 & 55.8 & 45.0 \\
\hline 12 & 41.0 & 54.5 & 58.7 & 51.4 & 36.3 & 52.7 & 57.9 & 49.0 \\
\hline Mean & 31.3 & 41.7 & 48.0 & & 28.9 & 41.4 & 47.0 & \\
\hline $\begin{array}{c}\text { L.S.D } 5 \% \\
\mathbf{N} \\
\mathbf{H} \\
\mathbf{N} \times \mathbf{K H} \\
\end{array}$ & & \multicolumn{2}{|c|}{3.2} & & \multicolumn{4}{|c|}{1.7} \\
\hline
\end{tabular}

\section{Plant fresh weight (g)}

Data in Table (5) showed that the highest the rate of fertilizer, the highest the fresh weight of the plant, so, addition of the highest rate of ammonium nitrate (4 g/ plant) produced 167.5 and $162.4 \mathrm{~g} /$ plant in 2015 and 2016 seasons, respectively.

In addition, a gradual increase of potassium humate was met with a significant gradual increase of the plant fresh weight. The highest level of potassium humate treatment $(12 \mathrm{~g} /$ plant) produced the highest fresh weight of the vegetative foliage (188.3 g and 184.7g) in 2015 and 2016 seasons, respectively. Similar results were reported by Renata et al. (2012) on (Ocimum basilicum L.) Plants, Ibrahim (2013) on datura (Datura innoxia Mill.) plants, Soha and Rabia (2014) on (Hibiscus sabdariffa L) and Shafeek et al. (2016) on summer squash plants.

Fayoum J. Agric. Res. \& Dev., Vol. 32, No.2, July, 2018 
Selim, S. M.*; et al.,

Table (5) : Effect of nitrogen and potassium humate (KH) on plant fresh weight (g) of Calotropis procera plant in two seasons.

\begin{tabular}{|c|c|c|c|c|c|c|c|c|}
\hline \multirow{2}{*}{$\mathrm{Humic} / \mathrm{g}_{\mathrm{NH}}^{\mathrm{NH}_{4} \mathrm{NO}_{3} / \mathrm{g}}$} & \multicolumn{4}{|c|}{ first season (2015) } & \multicolumn{4}{|c|}{ second season (2016) } \\
\hline & 1 & 2 & 4 & Mean & 1 & 2 & 4 & Mean \\
\hline $\mathbf{0}$ & 58.5 & 90.8 & 85.3 & 78.2 & 44.9 & 78.0 & 81.4 & 68.1 \\
\hline 4 & 93.4 & 146.6 & 184.2 & 141.4 & 98.2 & 152.3 & 177.5 & 142.7 \\
\hline 8 & 138.5 & 191.8 & 198.2 & 176.1 & 129.7 & 179.7 & 190.9 & 166.8 \\
\hline 12 & 164.2 & 198.4 & 202.2 & 188.3 & 169.1 & 185.2 & 199.8 & 184.7 \\
\hline Mean & 113.6 & 156.9 & 167.5 & & 110.5 & 148.8 & 162.4 & \\
\hline L.S.D $5 \%$ & \multirow{2}{*}{\multicolumn{4}{|c|}{7.98}} & \multirow{2}{*}{\multicolumn{4}{|c|}{3.53}} \\
\hline $\mathbf{N}$ & & & & & & & & \\
\hline KH & \multicolumn{4}{|c|}{4.58} & \multicolumn{4}{|c|}{5.77} \\
\hline $\mathbf{N} \times \mathbf{K H}$ & \multicolumn{4}{|c|}{7.94} & \multicolumn{4}{|c|}{10.00} \\
\hline
\end{tabular}

The interaction between $\mathrm{NH}_{4} \mathrm{NO}_{3}$ and potassium humate was significant. The most effect treatment in this respect was $\mathrm{NH}_{4} \mathrm{NO}_{3}$ at the rate of $4 \mathrm{~g} /$ plant and potassium humate at the rate of $12 \mathrm{~g} /$ plant. The most values were 202.2 and 199.8 in the two seasons, respectively.

\section{Plant dry weight (g):}

The results in Table (6) showed a significant increase in the dry weight of plant foliage with an increase in ammonium nitrate rate addition. The treatment with the highest rate of ammonium nitrate ( $4 \mathrm{~g} /$ plant) recorded the highest dry weight of plant foliage. The highest values were 37.5 and $37.1 \mathrm{~g}$ in the two seasons, respectively.

As for the effect of potassium humate, the results showed that the highest dry weight of the plant foliage were 40.8 and $39.9 \mathrm{~g}$ recorded from plants treated with potassium humate at $12 \mathrm{~g}$ / plant during 2015 and 2016, respectively. These results agreed with those obtained by Gholizadeh $\boldsymbol{e t}$ al. (2012) on tobacco, Renata et al. (2012) on (Ocimum basilicum L.) Plants, Ibrahim (2013) on datura (Datura innoxia Mill.) plants, Hendawy et al . (2015) on ( Mintha piperita ) var. Citrata and Ebrahimi and Miri (2016) on (Borago officinalis) and (Cichorium intybus) plants.

Fayoum J. Agric. Res. \& Dev., Vol. 32, No.2, July, 2018 
EFFECT OF AMMONIUM NITRATE AND POTASSIUM HUMATE.... 111 Table (6): Effect of nitrogen and potassium humate (KH) on dry weight of the above - ground vegetative growth (g)/ plant of Calotropis procera plant in two seasons.

\begin{tabular}{|c|c|c|c|c|c|c|c|c|}
\hline \multirow{2}{*}{ Humic/g $\mathrm{NH}_{4} \mathrm{NO}_{3} / \mathrm{g}$} & \multicolumn{4}{|c|}{ first season (2015) } & \multicolumn{4}{|c|}{ second season (2016) } \\
\hline & 1 & 2 & 4 & Mean & 1 & 2 & 4 & Mean \\
\hline $\mathbf{0}$ & 14.0 & 19.0 & 23.2 & 18.7 & 15.2 & 18.2 & 21.4 & 18.3 \\
\hline 4 & 19.7 & 25.5 & 35.5 & 26.9 & 20.3 & 25.0 & 34.9 & 26.7 \\
\hline 8 & 29.1 & 36.3 & 45.3 & 36.9 & 28.3 & 35.2 & 46.5 & 36.7 \\
\hline 12 & 32.4 & 43.8 & 46.2 & 40.8 & 31.6 & 42.7 & 45.4 & 39.9 \\
\hline Mean & 23.8 & 31.1 & 37.5 & & 23.9 & 30.3 & 37.1 & \\
\hline L.S.D $5 \%$ & \multirow{2}{*}{\multicolumn{4}{|c|}{1.1}} & \multirow{2}{*}{\multicolumn{4}{|c|}{1.5}} \\
\hline $\mathbf{N}$ & & & & & & & & \\
\hline KH & \multicolumn{4}{|c|}{1.0} & \multicolumn{4}{|c|}{1.2} \\
\hline $\mathbf{N} \times \mathbf{K H}$ & \multicolumn{4}{|c|}{1.7} & \multicolumn{4}{|c|}{2.1} \\
\hline
\end{tabular}

The interaction between $\mathrm{NH}_{4} \mathrm{NO}_{3}$ and potassium humate was significant. The highest values was 46.2 obtained from plants treated with $\mathrm{NH}_{4} \mathrm{NO}_{3}$ at $4 \mathrm{~g}$ / plant and potassium humate $12 \mathrm{~g} /$ plant in the first seasons, while in the second season was 46.5 obtained from plants treated with $\mathrm{NH}_{4} \mathrm{NO}_{3}$ at $4 \mathrm{~g}$ / plant and potassium humate $8 \mathrm{~g} /$ plant.

This results may due to that nitrogenous and potassium humate fertilizer increase the nutrients uptake by plants and consequently increased all vegetative growth characterstic such as plant height $(\mathrm{cm})$, number of branches per plant, number of leaves per plant, plant fresh weight $(\mathrm{g})$, plant dry weight $(\mathrm{g})$.

2. Chemical constituents

\subsection{Total phenolic content:}

Data in Table (7) show that the highest value of total phenolic content was $7.60 \mathrm{mg} / \mathrm{g}$ dry weight that obtained from plants treated by ammonium nitrat at $1 \mathrm{~g} /$ plant, while the lowest record was obtained from plants treated with the highest rate of ammonium nitrate ( $4 \mathrm{~g} / \mathrm{plant})$ during second season of study.

Fayoum J. Agric. Res. \& Dev., Vol. 32, No.2, July, 2018 
Selim, S. M.*; et al., 112

Table (7): Effect of nitrogen and potassium humate $(\mathrm{KH})$ on total phenolic content in leaves of Calotropis procera plant(mg / g dry weight ) during the second season (2016).

\begin{tabular}{|c|c|c|c|c|}
\hline \multirow{2}{*}{ Humic/g $\mathrm{NH}_{4} \mathrm{NO}_{3} / \mathrm{g}$} & \multicolumn{4}{|c|}{ second season (2016) } \\
\hline & 1 & 2 & 4 & Mean \\
\hline $\mathbf{0}$ & 8.45 & 6.58 & 6.16 & 7.07 \\
\hline 4 & 8.32 & 6.68 & 6.20 & 7.07 \\
\hline 8 & 7.01 & 7.10 & 5.79 & 6.63 \\
\hline 12 & 6.60 & 7.82 & 5.77 & 6.73 \\
\hline Mean & 7.60 & 7.05 & 5.98 & \\
\hline $\begin{array}{c}\text { L.S.D } 5 \% \\
\mathbf{N} \\
\mathbf{K H} \\
\mathbf{N} \times \mathbf{K H} \\
\end{array}$ & \multicolumn{4}{|c|}{$\begin{array}{l}0.16 \\
0.16 \\
0.27 \\
\end{array}$} \\
\hline
\end{tabular}

Regarding to effect of potassium humate, the results showed that the treatment with potassium humate at the lowest level ( $0 \mathrm{~g} /$ plant $)$ showed the highest content of total phenolic content $(7.07 \mathrm{mg} / \mathrm{g}$ dry weight) as compared to fertilization with the highest rate $(12 \mathrm{~g} /$ plant). Our results were in harmony with many investigators such as Phuong and Emily (2008) on basil (Ocimum basilicum L.) plants, Ibrahim et al. (2011) on Labisia pumila Benth plants and Munene et al. (2017) on two amaranth varieties.

The interaction between $\mathrm{NH}_{4} \mathrm{NO}_{3}$ and potassium humate was significant. The most effect treatment in this respect was $\mathrm{NH}_{4} \mathrm{NO}_{3}$ at the rate of $0 \mathrm{~g} /$ plant (control) and potassium humate at the rate of $0 \mathrm{~g} /$ plant (control). The most values was $8.45 \mathrm{mg} \mathrm{/} \mathrm{g}$ dry weight in the second seasons.

\subsection{Total flavonoids content:}

The results presented in Table (8) show that a significant decrease was obtained in total flavonoids content of plants with each level increase in ammonium nitrate addition. The treatment with the lowest rate of ammonium nitrate (1 g / plant) recorded the highest total flavonoids content $(8.41 \mathrm{mg} / \mathrm{g}$ dry weight ) in plants. This trend was noted in 2016.

Fayoum J. Agric. Res. \& Dev., Vol. 32, No.2, July, 2018 
EFFECT OF AMMONIUM NITRATE AND POTASSIUM HUMATE.... 113 Table (8): Effect of nitrogen and potassium humate $(\mathrm{KH})$ on total flavonoids content in leaves of Calotropis procera plant (mg / g dry weight ) during the second season (2016).

\begin{tabular}{|c|c|c|c|c|}
\hline \multirow{2}{*}{ Humic/g $\quad \mathrm{NH}_{4} \mathrm{NO}_{3} / \mathrm{g}$} & \multicolumn{4}{|c|}{ second season (2016) } \\
\hline & 1 & 2 & 4 & Mean \\
\hline $\mathbf{0}$ & 9.86 & 6.21 & 5.65 & 7.24 \\
\hline 4 & 8.46 & 7.21 & 6.07 & 7.25 \\
\hline 8 & 7.88 & 7.77 & 7.70 & 7.78 \\
\hline 12 & 7.42 & 6.42 & 6.06 & 6.64 \\
\hline Mean & 8.41 & 6.90 & 6.37 & \\
\hline $\begin{array}{c}\text { L.S.D } 5 \% \\
\mathbf{N} \\
\mathbf{K H} \\
\mathbf{N} \times \mathbf{K H}\end{array}$ & \multicolumn{4}{|c|}{$\begin{array}{l}0.34 \\
0.40 \\
0.69\end{array}$} \\
\hline
\end{tabular}

As regard to the effect of potassium humate, the results showed that the highest value of total flavonoids content was $7.78 \mathrm{mg} / \mathrm{g}$ dry weight that obtained from plants treated by potassium humate at $8 \mathrm{~g} /$ plant. While, the lowest record was $6.64 \mathrm{mg} / \mathrm{g}$ dry weight, which obtained from plants treated with the highest rate of potassium humate at $12 \mathrm{~g} /$ plant. Our results were in harmony with many investigators such as Phuong and Emily (2008) on basil (Ocimum basilicum L.) plants, Ibrahim et al. (2011) on Labisia pumila Benth plants and Munene et al. (2017) on two amaranth varieties.

The interaction between $\mathrm{NH}_{4} \mathrm{NO}_{3}$ and potassium humate was significant. The most effect treatment in this respect was $\mathrm{NH}_{4} \mathrm{NO}_{3}$ at the rate of $0 \mathrm{~g} /$ plant (control) and potassium humate at the rate of $0 \mathrm{~g} / \mathrm{plant}$ (control). The most values was $9,86 \mathrm{mg} / \mathrm{g}$ dry weight in the second seasons. This trend was the same trend in total phenolic content.

\subsection{Total alkaloids content:}

The results in Table (9) showed that the highest rate (4 g/plant) of produced the highest values of total alkaloids content $(0.781 \mathrm{~g} / 100 \mathrm{~g}$ dry weight) in the season 2016 as compared to fertilization with the other rates (1 and $2 \mathrm{~g} /$ plant).

Fayoum J. Agric. Res. \& Dev., Vol. 32, No.2, July, 2018 
Selim, S. M.*; et al.,

Table (9): Effect of nitrogen and potassium humate (KH) on total alkaloids content in leaves of Calotropis procera plant (g/100 g dry weight) during second season (2016).

\begin{tabular}{|c|c|c|c|c|}
\hline \multirow{2}{*}{ Humic/g $\mathbf{N H}_{\mathbf{4}} \mathbf{N O}_{\mathbf{3}} / \mathbf{g}$} & \multicolumn{4}{|c|}{ second season (2016) } \\
\cline { 2 - 5 } & $\mathbf{1}$ & $\mathbf{2}$ & $\mathbf{4}$ & Mean \\
\hline 0 & 0.500 & 0.650 & 0.685 & 0.611 \\
\hline 4 & 0.629 & 0.755 & 0.765 & 0.716 \\
\hline 8 & 0.688 & 0.793 & 0.825 & 0.751 \\
\hline 12 & 0.757 & 0.805 & 0.849 & 0.804 \\
\hline Mean & 0.644 & 0.751 & 0.781 & \\
\hline
\end{tabular}

Data also show that the gradual increase of potassium humate was met with a gradual increase of leaf total alkaloids content. The highest level of potassium humate treatment (12 g / plant) produced the highest values of total alkaloids content ( $0.804 \mathrm{~g} / 100 \mathrm{~g}$ dry weight). These results agreed with those obtained by Hossein et al. (2011) on (Nicotiana tabacum L.) plants, Ibrahim (2013) on datura plants, Zinab and Rabee (2016) on leaves of Catharanthus roseus and Kizil et al. (2017) on two henbane species (Hyoscyamus reticulatus L. and Hyoscyamus niger L.).

The interaction between $\mathrm{NH}_{4} \mathrm{NO}_{3}$ and potassium humate was significant. The highest value was 0.849 obtained from plants treated with $\mathrm{NH}_{4} \mathrm{NO}_{3}$ at $4 \mathrm{~g} /$ plant and potassium humate $12 \mathrm{~g} /$ plant in the second seasons.

From the above mentioned results, it could be recommended to cultivate this wild plant in a systematic culture for producing the active principles induding alkaloids and antioxidant materials induding total phenolics and total flavonoids. Fertilizing this plant with nitrogenous and potassium humate should taken into our account to promote the vegetative growth and consequently chemical constituents.

\section{REFRENCES}

A. O. A. C. 1992. Official Methods of Analysis, $12^{\text {th }}$ ed. Association of Official Analytical Chemists. Washington, D. C.

Ahmadi, M. 2010. Effect of zinc and nitrogen fertilizer rates on yield and yield components of oilseed rape (Brassica napus L.). J. Agric. \& Envi. Sci., 7(3): $259-264$

Ainsworth E.A, and E.M. Gillespie .2007. Estimation of total phenolic content and other oxidation substrates in plant tissue using folin - Ciocalteu reagent .Nature protocol , 2(4) : 875-877.

Fayoum J. Agric. Res. \& Dev., Vol. 32, No.2, July, 2018 
EFFECT OF AMMONIUM NITRATE AND POTASSIUM HUMATE.... 115

Aisha, H. A.; M. R. Shafeek ; R. M. Asmaa and M. El- Desuki .2014. Effect of various levels of organic fertilizer and humic acid on the growth and roots quality of turnip plants (Brassica rapa). Current Sci. Inter., 3(1): 7-14.

Azza, A. E. D.; S. F. Hendawy; E. A. Eman and E. A. Omer .2010. Enhancing growth, yield and essential oil of caraway (Carum carvi L.) plants; by nitrogen and potassium fertilizers. Interna. J. Academic Rese., 2(3): 192 197.

basis for yield differences . I . Growth analysis of six dry bean

Bhatti, R. M. B.; Z. A. N. Shah and S. D. Tunio .2011. Humic acid improves growth, yield and oil content of (Brassica Compestris L.) pak. J. Agri., Agril. Engg., Vet. Sci., 27(2): 125-133.

Dewan, S.; H. Sangraula and V. Kumar .2000. Preliminary studies on the analgesic activity of latex of Calotropris procera. J. Ethnopharmcol., 73, 307-11.

Ebrahimi, M. and E. Miri .2016. Effect of humic acid on seed germination and seedling growth of (Borago officinalis) and (Cichorium intybus). Ecopersia, 4(1): 1239-1249.

Farooq, A. M; M. T. Siddiqui; M. Ishaque and A. Tanveer.2014. Study of ethnobotany and indegenous use of Calotropis procera (Ait.) in Cholistan desert, Punjab,

Food chem, 64:555-559.

Gholizadeh, R.; N. M. Roshan ; S. M. Sadeghi, and H. Dorodian .2012. Study effects of different nitrogen and potassium fertilizers application amounts on quantitative and qualitative characteristics of tobacco (male sterile variety, PVH19) in Talesh region. Annals Biolog. Res., 3(11): 5323-5349.

Gomaa, A .O. and A. S. M. Youssef .2008. Efficiency of bio and chemical fertilization in presence of humic acid on growth performance of caraway. Thesis, Fac. Agric., Moshtohor, Benha Univ., Egypt.

Hafez, A. R. and D. S. Mikkelsen.1981. Colorimetric determination of nitrogen for evaluating the nutritional status of rice. Commun. Soil Sci. and Plant Analysis, 12 (1): 61- 69.

Hendawy, S. F.; M. S. Hussein ; A. E. El-Gohary and M. E. Ibrahim .2015. Effect of foliar organic fertilization on the growth, yield and oil content of Mentha piperita var. citrata. Asian J. Agri. Rese., 9 (5): 237-248.

Herbert, D; P.J. Phipps and R.E. Strange .1971. Determination of total carbohydrate. Methods in Microbiol 58: 204-344.

Hossein, H.; S. D. Morteza ; R. M. Hamid and A. M. Amir .2011. Effect of different nitrogen and potassium fertilizer levels on and quantity yield of flue-cured tobacco (coker 347). World Appli. Sci. J., 15(7): 941-946.

Ibrahim, M. H. ; Z. E. J. Hawa ; R. Asmah and A. R. Zaharah .2011. The relationship between phenolics and flavonoids production with total non structural carbohydrate and photosynthetic rate in (Labisia pumila Benth). under high CO2 and nitrogen fertilization . Molecules , (16): 162-174.

Fayoum J. Agric. Res. \& Dev., Vol. 32, No.2, July, 2018 
Selim, S. M.*; et al.,

Ibrahim, O. A. A. T. .2013. Effect of chemical and bio-fertilizers on growth and chemical constituents of datura (Datura Innoxia Mill.) plants. M.Sc. Thesis, Fac. Agric. Fayoum Univ.

Khairnar, A. K.; S. R. Bhamare and H. P. Bhamare. 2012. Calotropis procera: an ethnopharmacological update. Adv. Res. Pharm. Biol., 2(2): 142-56.

Kizil, S. ; Ö. Tonç er and T. Sogut. 2017. Effect of different nitrogen doses on some agricultural characteristics and alkaloid content of (Hyoscyamus reticulatus L.) and (Hyoscyamus niger L.). Cercetări Agron. în Moldova, 2(170): 8390.

Kumar, S.; A. Gupta and A. K. Pandey. 2013. Calotropis procera root extract has the capability to combat free radical mediated damage. ISRN Pharmacol., 2013 (691372): 1-8.

Mohammad Ali, S. A.; F. N. Alireza; N. Mehdi and H. Salvik .2012. Response of coker (flue- cured) tobacco (Nicotiana tabacum) to inoculation with Azotobacter chroococcum at various levels of nitrogen fertilization. Australian J. Crop Sci., 6 (5): 861-868.

Mohammadipour, E.; A. Golchin ; J. Mohammadi ; N. Negahdar and M. Zarchini .2012. Effect of humic acid on yield and quality of marigold (Calendula officinalis L.). Annals Biolog. Rese., 3 (11): 5095-5098.

Moran, R. 1982. Formula for determination of chlorophyllous pigments extracted with N, N-Dimethylfomamide. Plant Physiol, 69: 1376-1381.

Munene, R.; E. Changamu; N. Korir and G. O. Joseph .2017. Effects of different nitrogen forms on growth, phenolics, flavonoids and antioxidant activity in amaranth species. Soci. for Tropical Plant Rese. Inter. J. 4(1): 81-89.

Muzammal M. 2014. Study on antibacterial activity of Calotropis procera. Peer J PrePrints 2: 430 http://dx.doi.org/10.7287/peerj.preprints.430v1.; CC-BY 4.0 Open Access.

Nadia, G.; M. R. Abdel- Moez and K. Hala .2015. Response of okra (Hibiscus esculantus) growth and productivity to cobalt and humic acid rates. Inter. J. of ChemTech Rese., 8(4): 1782-1791.

Phuong, M. N. and D. N. Emily .2008. Effects of nitrogen fertilization on the phenolic composition and antioxidant properties of basil (Ocimum basilicum L.). Brown Working Papers in The Arts and Sciences, Southwestern University, Vol. VIII. Available at: http://www.southwestern.edu/ ademic/bwp/vol8/niemeyer-vol8.p

Rasmia, A. H; A. H. Amira and A. E. D. Azza .2009. Effect of nitrogen and potassium fertilization on growth, yield and alkaloidal content of periwinkle (Catharanthus roseus G. Don). Med. \& Arom. Plant Sci. \& Biotech., (3): 24-26.

Renata, N. W.; R. Ewa ; D. Katarzyna and B. Borowski .2012. Growth response to nitrogen and potassium fertilization of common basil (Ocimum basilicum

Fayoum J. Agric. Res. \& Dev., Vol. 32, No.2, July, 2018 
EFFECT OF AMMONIUM NITRATE AND POTASSIUM HUMATE.... 117

L.) Plants. Acta Scientiarum Polonorum, Hortorum Cultus, 11(2): 275288.

Rüveyde, T.; C. A. Esen and T. Murat .2011. The effects of nitrogen and sulphur fertilizers on the yield and quality of fenugreek (Trigonella foenumgraecum L.). Turkish J. of Field Crops, 16(1): 69-75.

Said- AlAhl, S. H. A. H.; A. G. El Gendy and E. A. Omer . 2016. Humic acid and indole acetic acid affect on yield and essential oil of dill grown under two different locations in Egypt. J. pharmace. Sci. and Rese., 8(7): 594-606.

Seifu T. 2004. Ethnobotanical and ethnopharmaceutical studies on medicinal plants of Chifra district, Afar region; MSC Thesis. North eastern Ethiopia: Addis Ababa Univ.

Shafeek, M. R.; Y. I. Helmy and A. A. Ahmed .2016. Productivity of squash plant to mineral and bio-nitrogen fertilizers on plant growth, total fruit yield and leaves mineral content on a sandy soil. Inter. J. ChemTech Res., 9(03): 66-75.

Snedecor, G.W. and W.G. Cochran. 1980. Statistical Methods. $7^{\text {th }}$ ed., lowa State Univ. press, Ames, lowa, USA.

Soha, E. Kh. and M. M.Y. Rabia .2014. Study the effect of irrigation water regime and fertilizers on growth, yield and some fruit quality of (Hibiscus sabdariffa L). Intern. J. of Adva. Rese., 2(5): 738-750.

Wallacee, O. H. and H. M. Munger. 1965. Studies on the physiological basis for yield differences . I . Growth analysis of six dry bean varieties . Crop Sci., 5:343-348.

Wilde, S. A.; R. B. Corey; J. G. Lyer and G. K. Voigt. 1985. Soil and Plant Analysis for Tree Culture. Oxford and IBM Publishers, New Delhi, India, $3^{\text {rd }}$ ed., 93 $-106$.

Woo, W. S.; , H. J. chi ; yun and S. Hye .1977. Alkaloids screening of same Saudi Arabian plants. Saengyak Hakhoe chi (Hanguk Saengya k Hakhoe), 8(3): 109- 113.

Zeinali, A. and P. Moradi .2015. The effects of humic acid and ammonium sulfate foliar spraying and their interaction effects on the qualitative and quantitative yield of native garlic (Allium sativum L.). J. Appli. Envi. \& Biologi. Sci., 4(12S): 205-211.

Zhishen, J. ; J. Mengcheng and W. Jianming .1999. The determination of flavonoid contents in mulberry and their scavenging effects an superoxide radicals. Food Chem, 64: 555-559.

Zinab, I. J. And K. M. Rabee .2016. Effect of salicylic and humic acid on vincristine and $\mathrm{n}, \mathrm{p}, \mathrm{k}$ content in madagascar periwinkle leaves. The Iraqi J. Agric. Sci., 47(2): 543-551.

Fayoum J. Agric. Res. \& Dev., Vol. 32, No.2, July, 2018 
تاثير نترات الامونيوم وحامض الهيوميك علي النمو الخضري والمكونات الكيميائية في نبات العشار

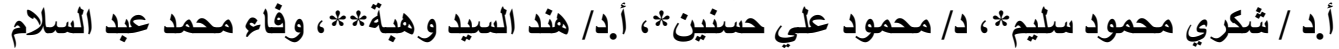

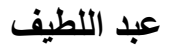

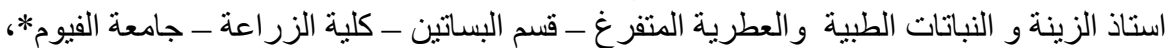

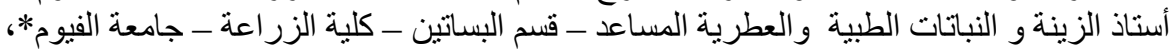

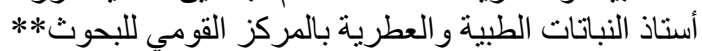

الخلاصة

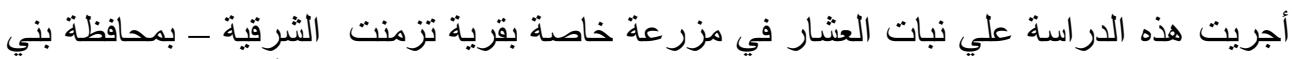

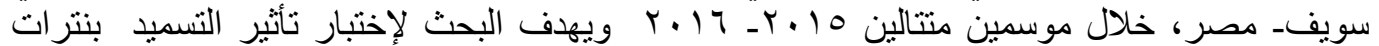

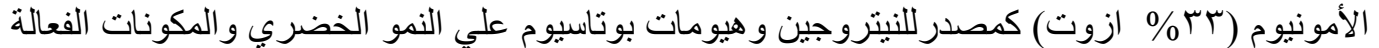
لنبات العشار (Calotropis procera).

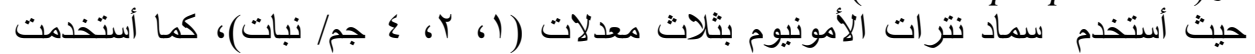

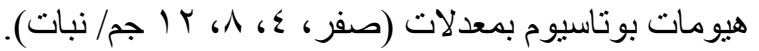

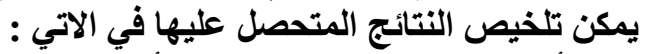

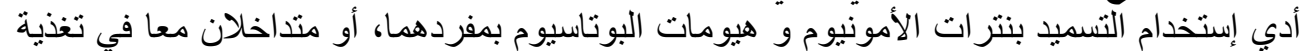

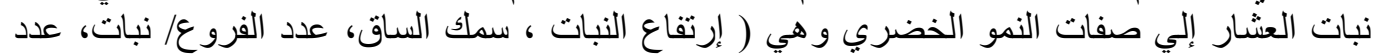

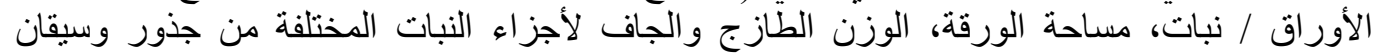

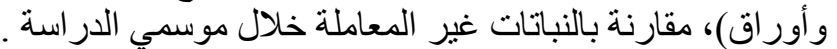

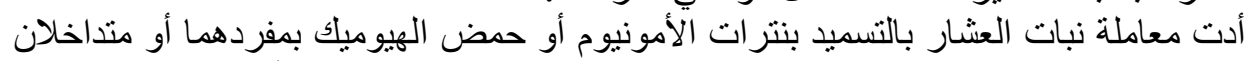

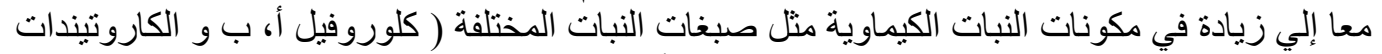

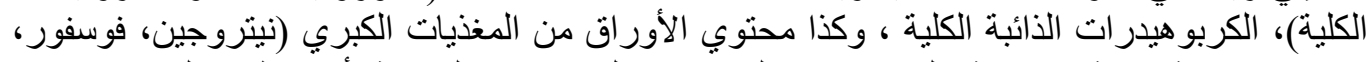

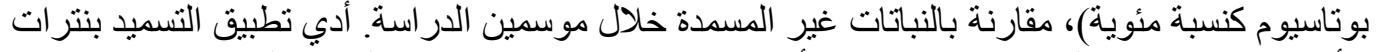

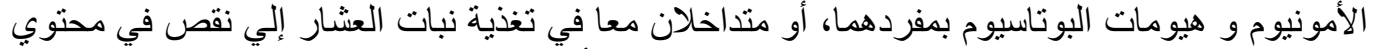

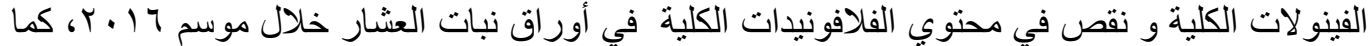

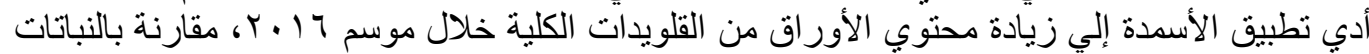

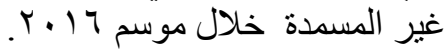

Fayoum J. Agric. Res. \& Dev., Vol. 32, No.2, July, 2018 